\title{
Reduction of Dacarbazine cytogenetic effects on somatic cells in male mice using bee glue (Propolis) to manifest the scientific miracles in the Quran
}

Lina Abdul-Fattah Kurdi, Fatimah Aliyan Aljeddani

Faculty of Sciences, Department of Biology "Zoology", Al Faisaliah Campus, King Abdul Aziz University, Kingdom of Saudi Arabia

\section{Type of article: Original}

\begin{abstract}
Objective: This study was carried out to investigate the ability of Propolis to ameliorate the adverse cytogenetic effects of Dacarbazine on bone marrow cells

Methods: In this experimental in vivo study, 18 mice were used, divided into four groups: control group; Propolis-treated group (treated with $50 \mathrm{mg} / \mathrm{kg}$ Propolis); and Dacarbazine-treated group (treated with $3.5 \mathrm{mg} / \mathrm{kg}$ Dacarbazine). The fourth, fifth, and sixth were treated with Dacarbazine and Propolis as pre $2 \mathrm{~h}$, post $2 \mathrm{~h}$, and concomitant treatment. After five days, the Bone Marrow (BM) samples were obtained for cytogenetic investigation.

Results: The in vivo studies revealed that Dacarbazine induced an abnormalities in polychromatic erythrocytes cells (PECs) as increase of cell with micronuclei, while the dual treatment accompanied with improvement of this abnormalities.

Conclusions: It could be concluded that there are protective effects of Propolis against the adverse effects of Dacarbazine. It could be recommended to use Propolis as an adjuvant with chemotherapeutic agents.

Keywords: Propolis, Dacarbazine, Bone marrow cells, Cytogenetic, Mice
\end{abstract}

\section{Introduction}

In the rapidly changing lifestyles of our present times, the use of synthetic chemicals, chemotherapeutic agents, and carcinogenic substances, as well as the widespread environmental pollutants, have negatively impacted human and other living organisms at the cellular and genetic levels. This is all the more dangerous because DNA genome sequence, carrying the genetic code, replicates semi-conservatively, handing down this tainted biological heritage from one generation to the next (1). The DNA molecule is continuously targeted by numerous carcinogenic and mutagenic agents that induce, either directly or indirectly, the production of free radicles, which react with each and every component of the DNA molecule, damaging its purine and pyrimidine bases $(2,3)$. Free radicals are primarily generated as a result of various metabolic processes and are generally regarded as essential for molecular organization processes. However, carcinogenic and mutagenic agents to which the human is continuously exposed leads to accumulation of free radicals in the body, compromising the ability of the biological system to remove toxins and repair the damage they cause, hence the oxidative phenomenon, which plays a major role in the development of many diseases (4-6). Natural products also have been known since the most ancient ages for their therapeutic values due to their varied chemical content, which helps preserve and develop self-defense mechanisms, represented by the natural cellular resistance, which protects the cells from toxic products and other environmental stresses. Many studies have indicated the usability of naturally occurring chemical substances as effective antioxidants that improve human health and protect against cancer and heart diseases. It is noteworthy here that antioxidants are both anti-mutagenic, i.e., protect against potential nucleic acid damage and anti-carcinogenic, i.e., prevent the development of secondary tumors without interfering with the therapeutic action of chemotherapeutic

\section{Corresponding author:}

Associate Professor Dr. Lina Abdul-Fattah Kurdi, Faculty of Sciences, Department of Biology "Zoology", Al Faisaliah Campus, King Abdul Aziz University, P.O. Box. 4938, Jeddah 21412, Kingdom of Saudi Arabia.

E-mail: dr.lina_kurdi@hotmail.com

Received: May 27, 2016, Accepted: July 28, 2016, Published: September 2016

iThenticate screening: July 28, 2016, English editing: August 25, 2016, Quality control: September 04, 2016

(C) 2016 The Authors. This is an open access article under the terms of the Creative Commons Attribution-NonCommercialNoDerivs License, which permits use and distribution in any medium, provided the original work is properly cited, the use is non-commercial and no modifications or adaptations are made. 
agents, whose efficacy it actually potentiates (4, 7-11). Evidence abounds as to the advisability of combining antioxidants with certain types of chemotherapeutic agents, due to their effectiveness in reducing neoplastic toxicity and limiting the generation of free radicals resulting from chemotherapy (12). Allah has created a multitude of natural products that may reduce the genetic toxicity associated with chemotherapy or caused by mutagenic agents, and it is a human duty to see how natural products can become a promising source of new medicines. God Almighty has spoken the truth when he said in his holy book: "Then eat all the fruits and follow the ways of your Lord laid down [for you]. There emerges from their bellies a drink, varying in colors, in which there is healing for people. Indeed, in that is a sign for a people who give thought" [Sura An-Nahl, verse 69]. Out of the verse, this study aspires to demonstrate the scientific miracles in the divine power healing that God placed in bee products (Propolis) and what lies in the diversity of compounds contained in the perfect consistency between effective in its material and its effectiveness, which may occur from the effects on cells' physical transaction result from Dacarbazine (DTIC) as anti-cancer drugs.

\section{Material and Methods}

\subsection{Animals used}

This experimental in vivo study was conducted on male albino mice (Mus Musculus, 2n = 40) of the MFI strain, aged 10-12 weeks, which have been obtained from the animal house of the King Fahd Medical Center located at King Abdulaziz University in Jeddah, where he developed these mice in special plastic cages under appropriate laboratory conditions in a well-ventilated private room. The water is provided daily along with fed dry rations in order to maintain the animal experiments.

\subsection{Dacarbazine (DTIC)}

Dacarbazine is chemotherapy used in cancer patients; its trade name is known as DETICENE, obtained from king Abdulaziz hospital in Jeddah.

\subsection{Propolis}

Bee glue, a material collected by bees from leaves' buds and has numerous benefits, and was obtained from Wild Honey Company in Saudi Arabia, Riyadh.

\subsection{Experimental Design}

Eighteen male mice were used in this study, which were divided into four main groups as follows: 1) Group 1 was treated with a distilled water; 2) Group 2 was treated with a 50mg/kg dose of bee glue (Propolis) (13); and 3) Group 3 was treated with a $3.5 \mathrm{mg} / \mathrm{kg}$ dose of Dacarbazine, adjusted for mice in accordance with the international adjusted dosage schedule (14); 4) Group 4 was treated with a combination of Propolis at a dose of 50mg/kg and Dacarbazine at a dose of $3.5 \mathrm{mg} / \mathrm{kg}$. Groups were further categorized into three categories as follows:

- Category a): receiving sequentially combined treatment with Propolis then $2 \mathrm{~h}$ Dacarbazine

- Category b): receiving simultaneous treatment with Propolis and Dacarbazine

- Category c): receiving sequentially combined treatment with Dacarbazine then $2 \mathrm{~h}$ Propolis

\subsection{Treatment}

Dacarbazine was administered by intraperitoneal injection (i.p.) (15). Propolis was administered via an orogastric tube (16) for five consecutive days. The technique suggested by Heddle (17) was followed in preparing bone marrow slices for the micronuclear test (Figure 1). To calculate the preventive effect, i.e., anti-mutagenic effect of Propolis against the mutagenic effect of Dacarbazine, the Serpeloni et al. equation was used (18).

\subsection{Statistical Analysis}

Statistical analysis was conducted on the basis of independent-samples t-test and analysis of variance (ANOVA) to calculate the significance of findings arrived at through the test under study. 


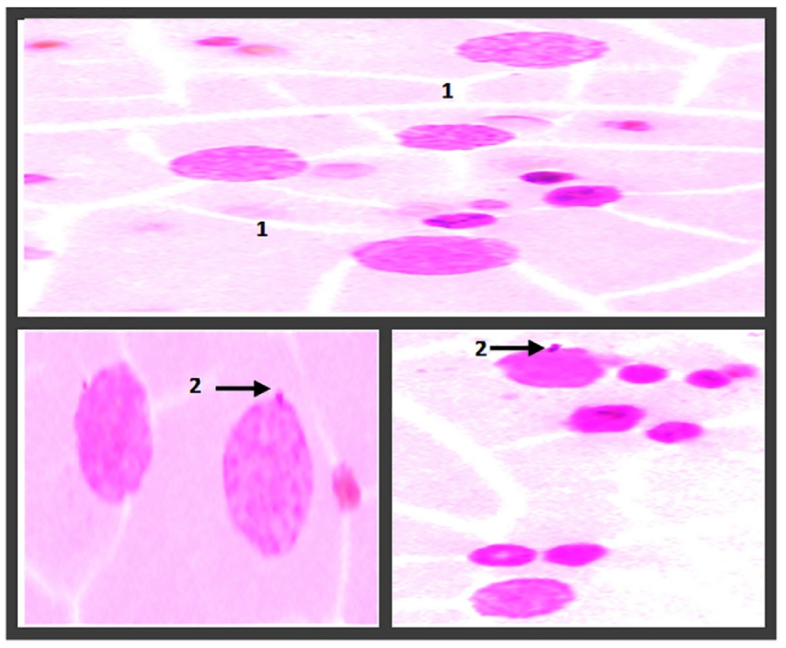

Figure 1. Micrographs show bone marrow cells in treated male mice and show where 1: polychromatic erythrocytes "normal"; 2: polychromatic erythrocytes with "micronucleus" (X1000)

\section{Results}

\subsection{The impact of sub-acute treatment with Propolis (bee glue)}

Results obtained 24 hours after the last treatment of male mice with a $50 \mathrm{mg} / \mathrm{kg}$ dose of Propolis (Table 1) showed that the number of micronuclei was slightly less than the control sample, valued at $5.67 \pm 0.88(0.57 \%)$. However, there were no significant differences in the mean appearance of micronucleated polychromatic erythrocytes (MNPCEs), compared with the control sample's value of $6.00 \pm 1.53$ (0.60\%) (Table 2, Figure 1 and 2).

Table 1. Number of mice and the amount of doses of different groups experience.

\begin{tabular}{|c|c|c|c|c|c|c|c|}
\hline \multicolumn{2}{|c|}{ Group 1 (C) } & \multicolumn{2}{|c|}{ Group $2(\mathrm{P})$} & \multicolumn{2}{|c|}{ Group 3 (T1) } & \multicolumn{2}{|c|}{ Group 4 (Propolis $+\mathrm{T} 1)$} \\
\hline $\mathrm{n}$ & Dose & $\mathrm{n}$ & Dose & $\mathrm{n}$ & Dose & $\mathrm{n}$ & Dose \\
\hline \multirow[t]{3}{*}{3} & \multirow[t]{3}{*}{$\begin{array}{l}\text { Physiological } \\
\text { solution }\end{array}$} & \multirow[t]{3}{*}{3} & \multirow[t]{3}{*}{$\begin{array}{l}(50 \mathrm{mg} / \mathrm{kg}) \\
\text { Propolis }\end{array}$} & \multirow[t]{3}{*}{3} & \multirow[t]{3}{*}{$\begin{array}{l}\text { T1A (DTIC } 3.5 \\
\mathrm{mg} / \mathrm{kg} \text { ) }\end{array}$} & 3 & $\begin{array}{l}\text { T2A (P } 50 \mathrm{mg} / \mathrm{kg} \rightarrow \text { DTIC } 3.5 \\
\mathrm{mg} / \mathrm{kg})\end{array}$ \\
\hline & & & & & & 3 & $\begin{array}{l}\text { T3A (P } 50 \mathrm{mg} / \mathrm{kg}+\text { DTIC } 3.5 \\
\mathrm{mg} / \mathrm{kg})\end{array}$ \\
\hline & & & & & & 3 & $\begin{array}{l}\text { T4A (DTIC } 3.5 \mathrm{mg} / \mathrm{kg} \rightarrow \text { P } 50 \\
\mathrm{mg} / \mathrm{kg} \text { ) }\end{array}$ \\
\hline
\end{tabular}

C: Control, P: Treatment with Propolis, T1: Treatment with Dacarbazine, P+T1: Treatment with Propolis \& Dacarbazine

Table 2. Effect of Propolis, treatments of Dacarbazine and the dual treatment with Propolis and Dacarbazine on the mean of polychromatic erythrocyte with micronucleus in male mice.

\begin{tabular}{|l|l|l|l|l|}
\hline $\begin{array}{l}\text { Groups } \\
\text { (treatment) }\end{array}$ & $\begin{array}{l}\text { Number of polychromatic } \\
\text { erythrocytes with } \\
\text { micronucleus }\end{array}$ & Mean \pm SE & $\begin{array}{l}\text { Rate of induction of } \\
\text { micronucleus }\end{array}$ & $\begin{array}{l}\text { Rate of antimutagens } \\
\text { effects }\end{array}$ \\
\hline C & 18 & $6.00 \pm 1.53$ & 0.60 & - \\
\hline P & 17 & $5.67 \pm 0.88$ & 0.57 & - \\
\hline T1A & 194 & $64.67 \pm 2.73 * \mathrm{a}$ & 6.47 & - \\
\hline T2A & 38 & $12.67 \pm 2.03 * \mathrm{~b}$ & 1.27 & 80.37 \\
\hline T3A & 88 & $29.33 \pm 2.85 * \mathrm{~b}$ & 2.93 & 54.71 \\
\hline T4A & 118 & $39.33 \pm 2.60 * \mathrm{~b}$ & 3.93 & 39.26 \\
\hline
\end{tabular}

C: Control, P: Propolis, T1A: Dacarbazine, T2A: Propolis $\rightarrow$ Dacarbazine, T3A: Propolis + Dacarbazine, T4A: Dacarbazine $\rightarrow$ Propolis, Comparison with $\mathrm{C}$, Comparison with T1A; a: Comparison with $\mathrm{C}$, b: Comparison with T1A, *p-value $<0.001$. 


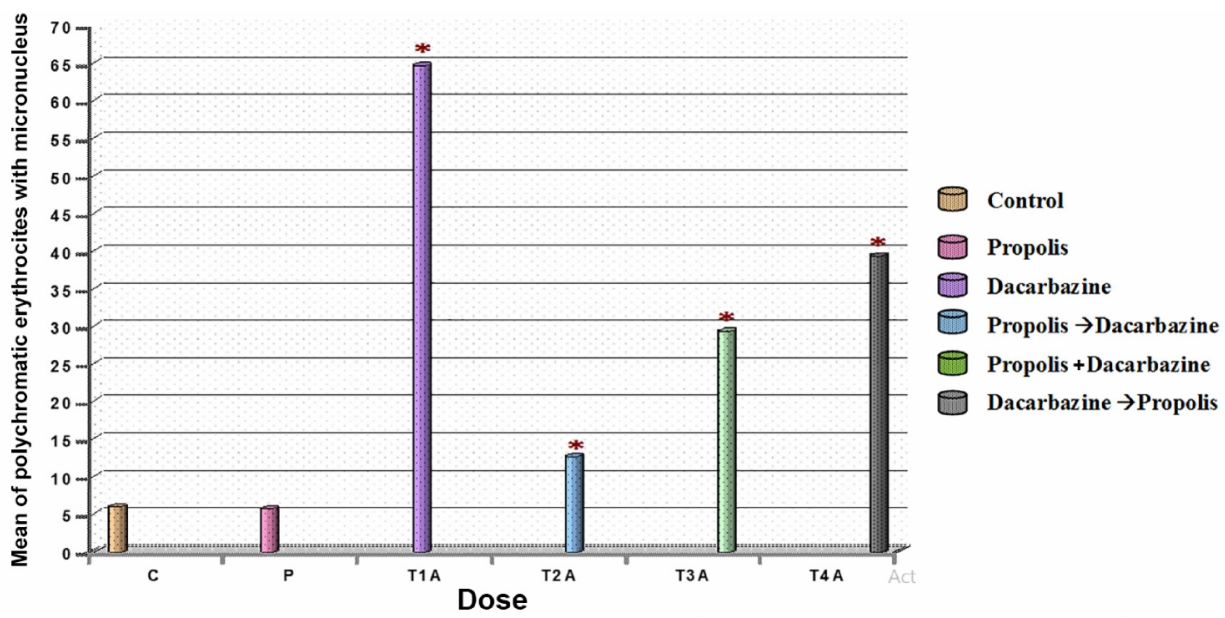

Figure 2. Effect of Propolis, of Dacarbazine and The Dual Treatment with Propolis and Dacarbazine on the mean of polychromatic erythrocytes with micronucleus in Male Mice

\subsection{The impact of sub-acute treatment with $3.5 \mathrm{mg} / \mathrm{kg}$ therapeutic dose of Dacarbazine}

Results obtained from Table 2 indicate Dacarbazine's high cytotoxicity to bone marrow cells of male mice treated with a $3.5 \mathrm{mg} / \mathrm{kg}$ therapeutic dose of Dacarbazine. Such treatment showed a highly significant increase $(\mathrm{p}<0.001)$ in the mean appearance of micronucleated polychromatic erythrocytes (MN-PCEs), valued at (64.67 \pm 2.73 ), estimated at $(6.47 \%)$, compared with the control sample (Figure 2$)$.

\subsection{Impact of sub-acute, combined treatment with Propolis and a $3.5 \mathrm{mg} / \mathrm{kg}$ therapeutic dose of Dacarbazine}

Examination of micronucleated polychromatic erythrocytes (MN-PCEs) of bone marrow cells of mice under subacute, combined treatment with a $50 \mathrm{mg} / \mathrm{kg}$ dose of Propolis and a $3.5 \mathrm{mg} / \mathrm{kg}$ therapeutic dose of Dacarbazine. Precedent, simultaneous, and subsequent sub-acute treatment showed a highly significant increase $(\mathrm{p}<0.001)$ in the mean appearance of micronucleated polychromatic erythrocytes (MN-PCEs), valued at (12.67 \pm 2.03 ), 29.33 \pm 2.85 , and $39.33 \pm 2.60$, estimated at $1.27 \%,(2.93 \%)$ and $3.93 \%$ respectively, compared with $64.67 \pm 2.73$, estimated at $6.47 \%$ resulting from sub-acute treatment with Dacarbazine at therapeutic dose of $3.5 \mathrm{mg} / \mathrm{kg}$. Calculation of the antimutagenic impact on the inducer of nucleoli revealed that precedent, simultaneous, and subsequent sub-acute combined treatment with both Propolis and Dacarbazine had caused a marked improvement, valued at $80.37 \%$, $54.71 \%$, and $39.26 \%$, respectively (Table 2, Figure 3).

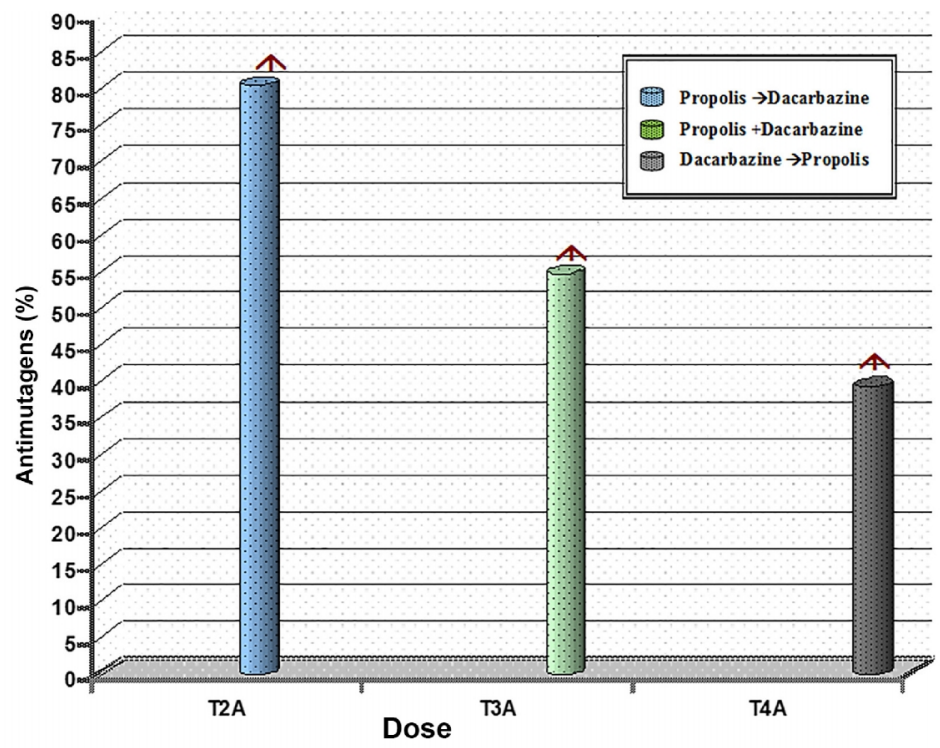

Figure 3. Effect of Dual Treatment with Propolis and Dacarbazine on the rate of antimutagens on induce micronucleus in Male Mice 
3.4. Comparing the impact of sub-acute treatment with either $50 \mathrm{mg} / \mathrm{kg}$ dose of Propolis or $3.5 \mathrm{mg} / \mathrm{kg}$ therapeutic dose of Dacarbazine, on the one hand, and the impact of combined, sub-acute treatment with both Propolis and Dacarbazine on the inducer of nucleoli, using analysis of variance and the least significant difference (LSD)

Results obtained from ANOVA indicate a highly significant increase $(\mathrm{p}<0.001)$ in the mean appearance of micronucleated polychromatic erythrocytes (MN-PCEs), valued at $(\mathrm{F}=108.60)$ between sub-acute treatment with either $50 \mathrm{mg} / \mathrm{kg}$ dose of Propolis or $3.5 \mathrm{mg} / \mathrm{kg}$ therapeutic dose of Dacarbazine, on the one hand, and the impact of combined, sub-acute treatment with both Propolis and Dacarbazine, compared with the control sample (Table 3). A comparison test, using the least significant difference, showed the highest significant difference to be $(p<0.001)$ in the mean appearance of micronucleated polychromatic erythrocytes (MN-PCEs), as a result of sub-acute treatment with Dacarbazine therapeutic dose and the simultaneous, and subsequence combined treatment with both Propolis and Dacarbazine and to be $(\mathrm{p}<0.05)$, as a result of combined, sub-acute, precedent treatment with Propolis and subsequent treatment with the chemotherapeutic agent. On the other hand, treatment with either Propolis did not post any significant difference in the mean appearance of micronucleated polychromatic erythrocytes (MN-PCEs) (Figure 4). Treatments, in terms of least impact on the inducer of nucleoli, can thus be placed in the following order: $\mathrm{P}<\mathrm{T} 2 \mathrm{~A}<\mathrm{T} 3 \mathrm{~A}<\mathrm{T} 4 \mathrm{~A}<\mathrm{T} 1 \mathrm{~A}$.

Table 3. ANOVA and LSD between the effect of treatment of Dacarbazine, Propolis and The Dual Treatment with Propolis and Dacarbazine on the mean of polychromatic erythrocytes with micronucleus

\begin{tabular}{|c|c|c|c|c|c|}
\hline \multirow[t]{2}{*}{ Statistics and groups } & \multicolumn{2}{|c|}{ ANOVA } & \multicolumn{3}{|l|}{ LSD } \\
\hline & $\mathrm{F}$ & $p$-value & Treatment group & Mean difference & $p$-value \\
\hline \multirow[t]{5}{*}{ Control (C) } & \multirow[t]{5}{*}{108.6} & \multirow[t]{5}{*}{$<0.001$} & $\mathrm{P}$ & 0.33 & \\
\hline & & & T1A & -58.67 & $<0.001$ \\
\hline & & & T2A & -6.67 & $<0.05$ \\
\hline & & & T3A & -23.33 & $<0.001$ \\
\hline & & & T4A & -33.33 & $<0.001$ \\
\hline
\end{tabular}

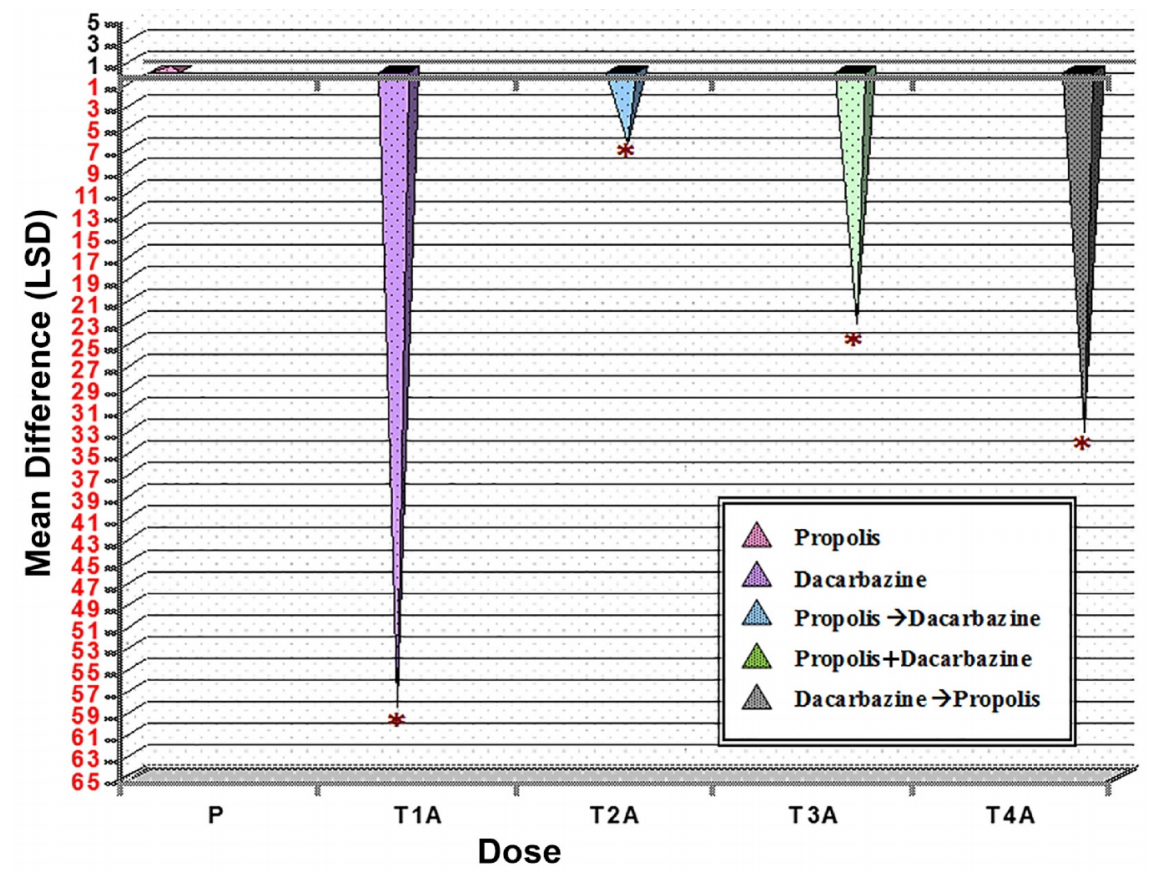

Figure 4. Comparison between The Effect of Treatment of Propolis, Dacarbazine and The Dual Treatment with Propolis and Dacarbazine on the mean of polychromatic erythrocytes with micronucleus by LSD

\section{Discussion and conclusions}

This study aimed at evaluating the potential genetic, cellular, and preventive impact of treatment with Propolis per se, combined, precedent, simultaneous, and subsequent treatment with Propolis and Dacarbazine and treatment with Dacarbazine per se. To achieve this goal, MFI albino mice of the species Mus Musculus, being mammals, were chosen, and a therapeutic dose of $3.5 \mathrm{mg} / \mathrm{kg}$ was also chosen for chemotherapeutic treatment of 8 -week-old male 
mice for five consecutive days. Results of the micronuclear test showed a highly significant ability of Dacarbazine to produce micronucleated polychromatic erythrocytes (MN-PCEs) in bone marrow cells of mice treated with a therapeutic dose of Dacarbazine, compared with the control sample. This is consistent with results arrived at by many previous researchers, who treated bone marrow cells using members of the group of alkylating anticancer drugs of which the drug under study, Dacarbazine, is also a member (19-22). Micronuclei originate from acentric chromatid or chromosomal splinters or from whole chromosomes that do not join the nucleus proper at the end of the final phase of cell division (telophase), due to a failure of proper connection to spindle fibers during the anaphase of cell division. These chromosomes or chromosomal splinters are joined together by means of a nuclear membrane and are small in size, compared with the size of the nucleus proper (23). Because micronuclei result from whole or splintered chromosomes joining together during the anaphase of cell division and are connected, as well, to the appearance and development of many types of tumors and negative cell division, they are usually used as biologic indicators of chromosomal aberrations or genetic mutations resulting from chemotherapeutic treatment and are ranked as the first tool to test the ability of chemical substances/chemotherapeutic agents to induce chromosomal anomalies/damage, whether numerical or structural (24-26), the micronuclear test being the most sensitive and the most powerful statistical tool to evaluate DNA breaks, which indicate potential mutations (27). Micronuclei form as a result of treatment with antineoplastic drugs that either cause direct damage to the nucleic acid or inhibit the cell cycle or damage the spindle fibers of mitotic division (28).

It was observed in previous studies that treatment with Dacarbazine had caused chromosomal aberrations/anomalies, chromosomal separation and chromatids gaps (29), DNA breaks in lymphocytes of patients undergoing Dacarbazine chemotherapy (30), and a considerable increase in micronuclei, which is considered as an indicator of genetic toxicity exerted by this drug on lymphocytes (31). In addition to those two mechanisms, micronuclei may form as a result of breaks in anaphasic bridges and may itself be the cause of development of bi-centric chromatids, interference of annular chromosomes, or union of sister chromatids (28). It was further proven that treatment of mice with the alkylating agent Dacarbazine at a dose of $30 \mathrm{mg} / \mathrm{kg}$ body weight led to depression and chromosomal anomalies, mostly in the form of chromatid gaps and breaks that are directly proportional to the dosage and duration of the chemotherapeutic agent (29). In 2002, Adler et al. conducted a test to determine Dacarbazine clastogenic impact on somatic cells, as well as on microbial cells in mice (32). The test showed that Dacarbazine-induced production of micronuclei in bone marrow cells, increasing progressively in proportion to the dose of the chemotherapeutic agent, ranging from $0-125 \mathrm{mg} / \mathrm{kg}$. Previous studies also confirmed Dacarbazine as a genotoxic and cytotoxic agent (33). Dacarbazine is also considered as a powerful oxidizing agent, as Dacarbazine-based chemotherapy leads to a release of free radicals, including types of reactive oxygen such as hydrogen peroxide, free hydroxyl radicals [OH-], known for its ability to destroy nucleic acids, and other vital cellular molecules (34, 35). Chemotherapy also reduces levels of antioxidant substances and enzymes in various tissues (7). By reducing antioxidants, which eliminate cytotoxicity induced by chemicals, including chemotherapeutic agents, by acting as free radical scavenging traps, treatment with Dacarbazine results in a deficient cellular defensive mechanism and increased oxidation processes, releasing free radicals, which are known for their ability to destroy cells and ultimately tissues. This is probably the most logical explanation for the consequences of treatment with Dacarbazine. The appearance of micronuclei in bone marrow cells of mice treated with a therapeutic dose of Dacarbazine, as evidenced by the current study, is, therefore, a credible proof of the genotoxic effects of this drug and an indicator of its mutagenicity. Combined, precedent, simultaneous, and subsequent treatment with Propolis and Dacarbazine caused a highly significant reduction in the numbers of micronuclei in micronucleated polychromatic erythrocytes (MN-PCEs) by 1.27\%, 2.93\%, and 3.93\%, respectively. This result is consistent with findings of previous studies that suggested the possibility of prevention of genotoxic effects resulting from chemotherapy, by using compounds that possess antioxidant properties, in vivo and in vitro.

Another study was conducted to evaluate both in vivo and in vitro anti-mutagenicity of Propolis in mice treated in vitro with Propolis in combination with daunomycin (DMC) and 2-aminofluorene (2AF) and in vivo with Propolis in combination with mitomycin (MMC) and cyclophosphamide (CP), all of which are known to lead to the formation of micronuclei in bone marrow cells of mice as well as to the development of chromosomal aberrations. Results showed that Propolis prevents the development of mutations as a consequence of treatment with (DMC) and (2AF) and that such prevention is directly dependent on dosage because Propolis was observed to prevent the formation of micronuclei at concentrations ranging from $45-135 \mathrm{mg} / \mathrm{kg}$ and to reduce the rate of recurrence of chromosomal aberrations at $135 \mathrm{mg} / \mathrm{kg}$ concentration. From those findings, we can safely conclude that Propolis is a good inhibitor of mutations resulting from in vitro treatment with (DMC) and (2AF), as well as in vivo treatment with CP and MMC (36). The results of the preventive effects study of different concentrations of Propolis against 
genotoxicity resulting from the treatment aflatoxin B1 (AFB1) in mice through the micronuclei test to increase the production of micronuclei in peripheral lymphocytes, treatment with Propolis decreased genotoxicity indicators that it causes by AFB1, which is attributed to the strong ability of Propolis to eliminate free radicals (37). Upon using hydrogen peroxide to induce damage to lymphocytic nucleic acid in order to evaluate the preventive or protective potential of Propolis, a marked reduction in hydrogen-peroxide-induced nucleic acid damage was observed in cells treated with Propolis. This may be attributable to the antioxidant activity of phenolic compounds contained in Propolis, which contributes to the limitation of nucleic acid damage resulting from hydrogen peroxide. Propolis has, therefore, a protective chemical activity, which may occur under various mechanisms (38). This study, thus, demonstrates that Dacarbazine has a genotoxic and mutagenic impact and contributes to chromosomal breakage, as was shown by the micronuclear test. Results obtained from this test indicate that sub-acute, combined, precedent, simultaneous, and subsequent treatment with Propolis and Dacarbazine limited the cytotoxic and genotoxic impact of sub-acute treatment with Dacarbazine per se. This study suggests, therefore, based on the previous findings, that the ability of Propolis to limit Dacarbazine cytotoxic and genotoxic effects may be attributable to Propolis being a potent antioxidant (39). Propolis antioxidant and anticancer activity may be linked to the antioxidant property of its individual active components $(39,40)$ such as: 1$)$ Group of vitamins of which the most important are vitamins B1, B2, B6, C, and E. Previous research attributed the anticancer activity of these substances as well as its ability to limit the cytotoxic and genotoxic effects of chemotherapy to the following mechanisms: Inhibition of estrogen receptors, induction of expression and activation of receptors of peroxide, which prevents cellular proliferation and inhibits nuclear receptors and which induce cellular growth and proliferation; induction of replicating agents, organizing antioxidation and detoxification, anti-inflammatory activities; induction of programmed cell death (apoptosis); enhancement of self-cellular phagocytosis and collagen production; enhancement of detoxification by P450 cytochrome; reduction of neoplastic genes; Scavenger of free radicals; enhancement of the immune system function (41-43); 2) flavonoids are a group of naturally occurring, low-molecular-weight substances, which possess many beneficial biological effects, including an anti-inflammatory, anti-allergic, antiviral, antioxidant, and anticancer effect, in addition to biologically protective effects, both in vivo and in vitro. The most important members of this group are quercetin, chrysin, caffeic acid phenethyl ester (CAPE), naringenin, glangin, acaacetin, apigenin, artepilin C. Previous studies proved that flavonoids' antioxidant impact is much more potent than that of vitamins $\mathrm{C}$ and $\mathrm{E}$ and that these compounds can prevent damage inflicted by free radicals via several mechanisms, namely, removal of reactive oxygen species ROS, activation of antioxidant enzymes, metal chelating activity, reduction of alphatocopherol radicals, inhibition of oxidases, alleviation of oxidative stress resulting from treatment with mutagenic agents, augmentation of antioxidant properties of low molecular antioxidants, reduction of P53 protein mutations, arresting cancer cell cycle, inhibition of tyrosine kinase, binding to estrogen receptors, inhibition of ROS proteins $(44,45)$. The sincerity of the Messenger of Allah, peace is upon him when he said: The whole Hand Such believer like bee ate good and put a good signed did not break and did not spoil.

\section{Acknowledgments:}

The authors sincerely thank the King Abdul Aziz University (Kingdom of Saudi Arabia) for contribution into this research.

\section{Conflict of Interest:}

There is no conflict of interest to be declared.

\section{Authors' contributions:}

Both authors contributed to this project and article equally. Both authors read and approved the final manuscript.

\section{References:}

1) Ren J, Singh BN, Huang Q, Li Z, Gao Y, Mishra P, et al. DNA hypermethylation as a chemotherapy target. Cell Signal. 2011; 23(7): 1082-93. doi: 10.1016/j.cellsig.2011.02.003. PMID: 21345368.

2) Valko M, Leibfritz D, Moncol J, Cronin MT, Mazur M, Telser J. Free radicals and antioxidants in normal physiological functions and human disease. Int J Biochem Cell Biol. 2007; 39(1): 44-84. doi: 10.1016/j.biocel.2006.07.001. PMID: 16978905.

3) Silverman RB, Holladay MW. The Organic Chemistry of Drug Design and Drug Action, 3rd Edition. Academic press. 2014.

4) Fang YZ, Yang S, Wu G. Free radicals, antioxidants, and nutrition. Nutrition. 2002; 18(10): 872-9. doi: 10.1016/S0899-9007(02)00916-4. PMID: 12361782. 
5) Gerald D, Berra E, Frapart YM, Chan DA, Giaccia AJ, Mansuy D, et al. JunD reduces tumor angiogenesis by protecting cells from oxidative stress. Cell. 2004; 118(6): 781-94. doi: 10.1016/j.cell.2004.08.025. PMID: 15369676.

6) Mena S, Ortega A, Estrela JM. Oxidative stress in environmental-induced carcinogenesis. Mutat Res. 2009; 674(1-2): 36-44. doi: 10.1016/j.mrgentox.2008.09.017. PMID: 18977455.

7) Elsendoorn TJ, Weijl NI, Mithoe S, Zwinderman AH, Van Dam F, De Zwart FA, et al. Chemotherapyinduced chromosomal damage in peripheral blood lymphocytes of cancer patients supplemented with antioxidants or placebo. Mutat Res. 2001; 498(1-2): 145-58. doi: 10.1016/S1383-5718(01)00278-9. PMID: 11673080.

8) da Rocha AB, Lopes RM, Schwartsmann G. Natural products in anticancer therapy. Curr Opin Pharmacol. 2001; 1(4): 364-9. doi: 10.1016/S1471-4892(01)00063-7. PMID: 11710734.

9) Conklin KA. Cancer chemotherapy and antioxidants. J Nutr. 2004; 134(11): 3201 -4. PMID: 15514307.

10) Weijl NI, Elsendoorn TJ, Lentjes EG, Hopman GD, Wipkink-Bakker A, Zwinderman AH, et al. Supplementation with antioxidant micronutrients and chemotherapy-induced toxicity in cancer patients treated with cisplatin-based chemotherapy: a randomised, double-blind, placebo-controlled study. Eur J Cancer. 2004; 40(11): 1713-23. doi: 10.1016/j.ejca.2004.02.029. PMID: 15251161.

11) Shen DW, Pouliot LM, Hall MD, Gottesman MM. Cisplatin resistance: a cellular self-defense mechanism resulting from multiple epigenetic and genetic changes. Pharmacol Rev. 2012; 64(3): 706-21. doi: 10.1124/pr.111.005637. PMID: 22659329, PMCID: PMC3400836.

12) Drisko JA, Chapman J, Hunter VJ. The use of antioxidant therapies during chemotherapy. Gynecol Oncol. 2003; 88(3): 434-9. doi: 10.1016/S0090-8258(02)00067-7. PMID: 12648599.

13) Reda H., Azza A., and Nahla S. Protective role of Propolis ageinst reproductive toxicity of chlorpyrifos in male rats. Pesticide Biochemistry and Physiology,2011; 101(3): 175-81, doi: 10.1016/j.pestbp.2011.09.003

14) Hardman, J.G, Limbird, L.E. and Gilman, A.G. Goodman and Gilman's the pharmacological basis of therapeutics, 2006, 10Ed.

15) Anton E. Ultrastructural Changes of Stromal Cells of Bone Marrow and Liver After Cyclophosphamide Treatment in Mice. Tissue Cell. 1997; 29(1): 1-9. doi: 10.1016/S0040-8166(97)80066-3. PMID: 9061976.

16) Sakr SA, Zoil Mel-S, El-Shafey SS. Ameliorative Effect of Grapefruit Juice on Amiodarone-Induced Cytogenetic and Testicular Damage in Albino Rats. Asian Pac J Trop Biomed. 2013; 3(7): 573-9 doi: 10.1016/S2221-1691(13)60116-1. PMID: 23836512, PMCID: PMC3695585.

17) Heddle JA. A rapid in vivo test for chromosomal damage. Mutat Res. 1973; 18(2): 187-90. PMID: 4351282.

18) Serpeloni JM, Bisarro dos Reis M, Rodrigues J, Campaner dos Santos L, Vilegas W, Varanda EA, et al. In vivo assessment of DNA damage and protective effects of extracts from Miconia species using the comet assay and micronucleus test. Mutagenesis. 2008; 23(6): 501-7. doi: 10.1093/mutage/gen043. PMID: 18765422.

19) Gebel T, Lantzsch H, Plessow K, Dunkelberg H. Genotoxicity of platinum and palladium compounds in human and bacteria cells. Mutat Res. 1997; 389(2-3): 183-90. doi: 10.1016/S1383-5718(96)00145-3ax. PMID: 9093382.

20) Kurdi L. The ability of Honey Bee to alleviate the histological, cytological and cytogenetic effects of cisplatin in mice. M. SC. thesis Submitted to Grils College of Education, Zoolgy Department, Jeddah, Kingdom of Saudi Arabia. 2000s.

21) Karpova GV, Fomina TI, Voronova OL, Abramova EV, Loskutova OP. Early and delayed effects of carboplatin on the blood system. Bull Exp Biol Med. 2001; 132(5): 1065-9. doi: 10.1023/A:1017964407835. PMID: 11865323.

22) Al-Etaby MK, Abou-Tarboush FM. Clastogenic effects of carboplatin on SWR/J mouse bone marrow cells. Arab J Biotech. 2004; 7(1): 75-82.

23) Fenech M, Kirsch-Volders M, Natarajan AT, Surralles J, Crott JW, Parry J, et al. Molecular mechanisms of micronucleus, nucleoplasmic bridge and nuclear bud formation in mammalian and human cells. Mutagenesis. 2011; 26(1): 125-32. doi: 10.1093/mutage/geq052. PMID: 21164193.

24) Grover IS, Kaur S. Genotoxicity of wastewater samples from sewage and industrial effluent detected by the Allium root anaphase aberration and micronucleus assays. Mutat Res. 1999; 426(2): 183-8. doi: 10.1016/S0027-5107(99)00065-2. PMID: 10350595.

25) Krishna G, Hayashi M. In vivo rodent micronucleus assay: protocol, conduct and data interpretation. Mutat Res. 2000; 455(1-2): 155-66. doi: 10.1016/S0027-5107(00)00117-2. PMID: 11113474. 
26) Bakare AA, Okunola AA, Adetunji OA, Jenmi HB. Genotoxicity assessment of a pharmaceutical effluent using four bioassays. Genet Mol Biol. 2009; 32(2): 373-81. doi: 10.1590/S1415-47572009000200026. PMID: 21637694, PMCID: PMC3036925.

27) Araldi RP, de Melo TC, Mendes TB, de Sá Júnior PL, Nozima BH, Ito ET, et al. Using the comet and micronucleus assays for genotoxicity studies: a review. Biomed Pharmacother. 2015; 72: 74-82. doi: 10.1016/j.biopha.2015.04.004. PMID: 26054678.

28) Samanta S, Dey P. Micronucleus and its applications. Diagn Cytopathol. 2012; 40(1): 84-90. doi: 10.1002/dc.21592. PMID: 22180242.

29) al-Hawary BA, al-Saleh AA. cytogenetic effects of dacarbazine on mouse bone marrow cells in vivo. Mutat Res. 1989; 223(2): 259-66. doi: 10.1016/0165-1218(89)90054-2. PMID: 2739683.

30) Walles SA, Ringborg U. Induction and time course of DNA single-strand breaks in lymphocytes from patients treated with dacarbazine. Carcinogenesis. 1991; 12(6): 1153-4. doi: 10.1093/carcin/12.6.1153. PMID: 2044200.

31) Khan MI, Ahmad I, Mahdi AA, Akhtar MJ, Islam N, Ashquin M, et al. Elevated blood lead levels and cytogenetic markers in buccal epithelial cells of painters in India: genotoxicity in painters exposed to lead containing paints. Environ Sci Pollut Res Int. 2010; 17(7): 1347-54. doi: 10.1007/s11356-010-0319-x. PMID: 20300868.

32) Adler ID, Kliesch U, Jentsch I, Speicher MR. Induction of chromosomal aberrations by dacarbazine in somatic and germinal cells of mice. Mutagenesis. 2002; 17(5): 383-9. doi: 10.1007/s11356-010-0319-x. PMID: 12202625.

33) Kumar SG, Narayana K, Bairy KL, D'Souza UJ, Samuel VP, Gopalakrishna K. Dacarbazine induces genotoxic and cytotoxic germ cell damage with concomitant decrease in testosterone and increase in lactate dehydrogenase concentration in the testis. Mutat Res. 2006; 607(2): 240-52. doi: 10.1016/j.mrgentox.2006.04.019. PMID: 16793327.

34) Pourahmad J, Amirmostofian M, Kobarfard F, Shahraki J. Biological reactive intermediates that mediate dacarbazine cytotoxicity. Cancer Chemother Pharmacol. 2009; 65(1): 89-96. doi: 10.1007/s00280-0091007-8. PMID: 19399501.

35) Quita SM. Evaluation of antioxidant activity of propolis (bee glue) on the histopathology of hepatocytes in mice treated with dacarbazine. Journal of American Science. 2016; 12(3).

36) Fu JY, Xia Y, Zheng YY. Antimutagenicity of propolis against some mutagens in vivo and in vetro. Biomed Environ Sci. 2004; 17(4): 469-75. PMID: 15745252.

37) Türkez H, Yousef MI. Propolis ameliorates human peripheral blood lymphocytes from DNA damage caused by aflatoxin B1. Journal of Biological and Environmental Sciences. 2009; 3(9): 77-80.

38) Aliyazicioglu Y, Demir S, Turan I, Cakiroglu TN, Akalin I, Deger O, et al. Preventive and protective effects of turkish propolis on $\mathrm{H} 2 \mathrm{O} 2$-induced DNA damage in foreskin fibroblast cell lines. Acta Biol Hung. 2011; 62(4): 388-96. doi: 10.1556/ABiol.62.2011.4.5. PMID: 22119868.

39) Banskota AH, Nagaoka T, Sumioka LY, Tezuka Y, Awale S, Midorikawa K, et al. Antiproliferative activity of the Netherlands propolis and its active principles in cancer cell lines. J Ethnopharmacol. 2002; 80(1): 67-73. doi: 10.1016/S0378-8741(02)00022-3. PMID: 11891088.

40) Stan L, Mărghitaş LA, Dezmirean D. Quality criteria for propolis standardization. Scientific Papers Animal Science and Biotechnologies. 2011; 44(2): 137-40.

41) Smolarek AK, Suh N. Chemopreventive activity of vitamin E in breast cancer: a focus on $\gamma$-and $\delta$ tocopherol. Nutrients. 2011; 3(11): 962-86. doi: 10.3390/nu3110962. PMID: 22254089, PMCID: PMC3257724.

42) Kang TH, Knoff J, Yeh WH, Yang B, Wang C, Kim YS, et al. Treatment of tumors with vitamin E suppresses myeloid derived suppressor cells and enhances CD8+ T cell-mediated antitumor effects. PloS one. 2014; 9(7): 103562. doi: 10.1371/journal.pone.0103562. PMID: 25072795, PMCID: PMC4114790.

43) Khan M, Iqubal A, Joshi A, Ajai K. Role of antioxidants in prevention of cancer: A review. International Journal of Current Research and Review. 2014; 6(9): 80-8.

44) Procházková D, Boušová I, Wilhelmová N. Antioxidant and prooxidant properties of flavonoids. Fitoterapia. 2011; 82(4): 513-23. doi: 10.1016/j.fitote.2011.01.018.

45) Kumar S, Pandey AK. Chemistry and biological activities of flavonoids: an overview. Scientific World Journal. 2013; 2013: 162750. doi: 10.1155/2013/162750. PMID: 24470791 , PMCID: PMC3891543. 